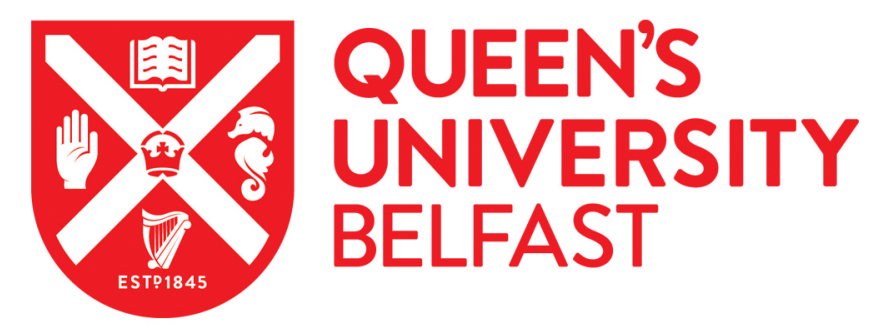

\title{
Paleolimnological proxies reveal continued eutrophication issues in the St. Lawrence River Area of Concern
}

Moir, K. E., Hickey, M. B. C., Leavitt, P. R., Ridal, J. J., \& Cumming, B. F. (2018). Paleolimnological proxies reveal continued eutrophication issues in the St. Lawrence River Area of Concern. Journal of Great Lakes Research, 44(3), 357-366. https://doi.org/10.1016/j.jglr.2018.02.001

Published in:

Journal of Great Lakes Research

Document Version:

Peer reviewed version

Queen's University Belfast - Research Portal:

Link to publication record in Queen's University Belfast Research Portal

Publisher rights

(C) 2018 International Association for Great Lakes.

This manuscript version is made available under the CC-BY-NC-ND 4.0 license http://creativecommons.org/licenses/by-nc-nd/4.0/,which permits distribution and reproduction for noncommercial purposes, provided the author and source are cited

\section{General rights}

Copyright for the publications made accessible via the Queen's University Belfast Research Portal is retained by the author(s) and / or other copyright owners and it is a condition of accessing these publications that users recognise and abide by the legal requirements associated with these rights.

Take down policy

The Research Portal is Queen's institutional repository that provides access to Queen's research output. Every effort has been made to ensure that content in the Research Portal does not infringe any person's rights, or applicable UK laws. If you discover content in the Research Portal that you believe breaches copyright or violates any law, please contact openaccess@qub.ac.uk. 
2 Paleolimnological proxies reveal continued eutrophication issues in the St. Lawrence River Area 3 of Concern

4

5 Katherine E. Moir ${ }^{\mathrm{a}, \mathrm{b},{ }^{*}}$, M. Brian C. Hickey ${ }^{\mathrm{a}, \mathrm{b}}$, Peter R. Leavitt ${ }^{\mathrm{c}, \mathrm{d}}$, Jeffrey J. Ridal ${ }^{\mathrm{a}, \mathrm{b}}$, and Brian F. 6 Cumming ${ }^{\mathrm{a}, \mathrm{e}}$

$8{ }^{a}$ School of Environmental Studies, Queen's University, Kingston, Ontario, Canada K7L 3J9

$9{ }^{\mathrm{b}}$ St. Lawrence River Institute of Environmental Sciences, Cornwall, Ontario, Canada, K6H 4Z1

$10{ }^{\mathrm{c}}$ Limnology Laboratory, Department of Biology, University of Regina, Regina, Saskatchewan,

11 Canada, S4S 0A2

$12{ }^{\mathrm{d}}$ Institute of Environmental Change and Society, University of Regina, Regina, Saskatchewan,

13 Canada, S4S 0A2

$14{ }^{\mathrm{e}}$ Paleoecological Environmental Assessment and Research Laboratory, Department of Biology,

15 Queen's University, Kingston, Ontario, Canada, K7L 3N6

$16 *$ Corresponding author contact information: katherine.moir@queensu.ca, +1 613-540-0889

17 Author contact information:

18 M. B. C. Hickey: bhickey@ riverinstitute.ca, 613-936-6620 ext. 225

19 P. R. Leavitt: peter.leavitt@uregina.ca, 306-585-4253

20 J. J. Ridal: jridal@ $@$ riverinstitute.ca, 613-936-6620 ext. 228

21 B. F. Cumming: brian.cumming@queensu.ca, 613-533-6153 
Abstract

23 Recent surface-water surveys suggest that high nutrient concentrations and nuisance algae

24 remain issues in the St. Lawrence River Area of Concern (AOC) at Cornwall, Ontario,

25 specifically in the tributaries and nearshore zones of Lake St. Francis (LSF). In particular, it is

26 unclear whether management actions designed to reduce nutrient inputs, first implemented in the

27 1990s as part of the Remedial Action Plan for the AOC, have reduced algal production or

28 influenced assemblage composition. To address this issue, a paleolimnological approach was

29 used to provide a historical context for the present-day nutrient concentrations and to quantify

30 the extent of change in water quality in LSF since the early 1990s. A sediment core was

31 collected near the north shore of LSF and was examined for changes in the concentrations and

32 compositions of fossil diatoms and pigments, as well as stable isotope $\left(\delta^{15} \mathrm{~N}\right.$ and $\left.\delta^{13} \mathrm{C}\right)$ values.

33 Analyses of diatom and pigment concentrations indicated that overall algal abundance has risen

34 in the last few decades, including trends of increasing occurrences of potentially toxic

35 cyanobacteria, despite ongoing remediation efforts. Temporal patterns of stable isotope

36 signatures in the core suggest a steady increase in nutrient influx since the mid- $20^{\text {th }}$ century, with

37 the post-1990 increase in algal production likely attributable to recent inputs associated with

38 land-use changes in local contributing watersheds. These patterns suggest that the AOC delisting

39 goals for the LSF tributaries will not be reached without a drastic change in land management

40 practices.

\section{Keywords}

42 Eutrophication, paleolimnology, St. Lawrence River, pigments, diatoms, stable isotopes 


\section{Introduction}

45 Within the Laurentian Great Lakes Basin, 43 Areas of Concern (AOCs) have been

46 identified by the International Joint Commission as regions that have experienced environmental

47 degradation as a result of biological, chemical, or physical changes in the aquatic ecosystem

48 (Dreier et al., 1997; International Joint Commission, 2003a). The St. Lawrence River near

49 Cornwall, ON, and Massena, NY, is the easternmost AOC where environmental issues arose

50 from intensive industrial and agricultural activities, habitat loss and degradation, as well as from

51 hydrodynamic changes from anthropogenic modifications to the waterway such as the

52 construction of the St. Lawrence Seaway (Anderson et al., 1992). Two Remedial Action Plans

53 (RAPs) were developed for the St. Lawrence River AOC at Cornwall and Massena, serving to

54 identify and remediate beneficial use impairments (BUIs; International Joint Commission, 2012)

55 in the Canadian and U.S. portions of the AOC, respectively. Within the Canadian section of the

56 AOC, many of the identified environmental stressors have been mitigated through regulations

57 and local action, including reductions in the concentrations of harmful bacteria, improved

58 management of fish populations, and restrictions on industrial discharges to the waterway

59 (Environment Canada and Ontario Ministry of the Environment, 2010). However, three BUIs

60 remain impaired in this AOC, including eutrophication and the presence of undesirable algae

61 (e.g., toxic cyanobacterial blooms), a problematic issue in the nearshore zones and tributaries of

62 the fluvial lake known as Lake St. Francis (LSF; Environment Canada and Ontario Ministry of

63 the Environment, 2010).

64 Increased nutrient loadings from the LSF watersheds, faulty septic systems in nearshore

65 communities, changes to the hydraulics of the system from seaway construction, and climate

66 change have all been suggested as contributing sources of the nuisance eutrophication and algal 
67 blooms in the AOC (Anderson et al., 1992; The St. Lawrence River (Cornwall) RAP Team,

68 1995). Although only 5\% of the water in LSF originates in its tributaries (Anderson et al., 1992),

69 the large proportion of agricultural land in the contributing watersheds could disproportionately

70 affect nutrient loadings to LSF and impair water quality in nearshore areas. Remediation goals

71 for eutrophication in the AOC originally included mean summer tributary and nearshore total

72 phosphorus (TP) concentrations $\leq 30 \mu \mathrm{g} / \mathrm{L}$ and no eutrophication-related fish kills (Dreier et al.,

73 1997). The targets for TP concentration in the tributaries were updated in 2009 to reflect

74 proportional goals based on the amount of agricultural activity in each watershed, ranging from

75 35-60 $\mu \mathrm{g} / \mathrm{L}$ (AECOM Canada Ltd., 2009; J. Ridal, pers. comm.). The TP target for the main

76 body of LSF, beyond the $2-\mathrm{m}$ isopleth, remains at $20 \mu \mathrm{g} / \mathrm{L}$ and is not currently considered

77 impaired.

78 Since the early 1990s, efforts to reduce eutrophication in LSF have primarily targeted

79 nutrients emanating from local farms and those from the city of Cornwall. Actions have included

80 tributary restoration programs (including tree planting along tributary banks and fencing to

81 restrict cattle access to streams), upgrades to septic systems, reductions in agricultural runoff

82 through the Nutrient Management Act (2002), upgrades to the city of Cornwall wastewater

83 treatment plant, and reductions in the number of combined sewers in the city of Cornwall

84 (Environment Canada and Ontario Ministry of the Environment, 2010). Unfortunately,

85 monitoring of the water-quality and ecological responses to these actions has been limited,

86 hampering the ability to assess potential eutrophication declines in LSF. Monitoring data for both

87 TP and algal abundance and community structure are sparse prior to the last decade (Pilon and

88 Chrétien, 1991; Reavie et al., 1998; Richman et al., 1997), and it remains unclear if and how 
89 algal communities in the tributaries and nearshore zones of LSF have responded to remedial 90 actions.

91 Provided that the sediment has remained relatively undisturbed, paleolimnological

92 approaches can be applied to LSF to examine how algal assemblages have responded to the

93 implementation of the RAP, and how those communities have changed over time. Previous

94 paleolimnological characterisations of the eastern end of LSF, collected in the early 1990s,

95 suggested that diatom communities responded to the known period of eutrophication in the Great

96 Lakes in the mid- $20^{\text {th }}$ century, and additionally responded to well-documented macrophyte

97 growth in the region (Reavie et al., 1998). However, less is known about historical changes in

98 other groups of primary producers, including potentially toxin-producing cyanobacteria such as

99 Anabaena and Microcystis (Carmichael, 2001), occurrences of which have been reported in this

100 region in recent years (Bramburger, 2014; Waller et al., 2016). Paleolimnological techniques

101 have been successfully applied to other AOCs (e.g., Alexson et al., 2017; Dixit et al., 1998),

102 providing valuable information to stakeholders regarding historical environmental changes to the

103 impacted systems.

104 The objective of the current study is to assess the degree to which the abundance and 105 composition of algal communities in the nearshore areas of LSF have changed since the 106 implementation of the RAP in the early-1990s. Although some surface-water sampling has been 107 conducted in recent years, the response of algal assemblages to actions implemented as part of

108 the RAP has not been examined, despite ongoing concerns regarding high nutrient

109 concentrations and algal blooms in the AOC, including occurrences of toxin-producing

110 cyanobacteria (Bramburger, 2014; Environment Canada and Ontario Ministry of the

111 Environment, 2010; Savard et al., 2013, 2015). To address this issue, we quantified sedimentary 
112 concentrations of photosynthetic pigments known to reliably indicate historical changes in

113 abundances of primary producers (Hall et al., 1999; Leavitt and Findlay, 1994), fossil diatom

114 assemblages to infer past environmental conditions along the impacted northern shore of LSF

115 (Battarbee et al., 2002; Reavie and Edlund, 2010), and carbon (C) stable isotopes to evaluate

116 temporal changes in production and C sources (Hodell and Schelske, 1998; Savage et al., 2010).

117 In addition, stable isotopes of nitrogen $(\mathrm{N})$ were used to infer historical changes in nutrient

118 sources arising from changes in aquatic production $\left(\mathrm{N}_{2}\right.$ fixation), agriculture within the

119 watershed, or regional urban development (Bunting et al., 2016; Leavitt et al., 2006). These

120 proxies can be used to provide a comprehensive overview of changes to algal abundance,

121 production, and composition, suitable to evaluate water quality status. This information is

122 valuable to the St. Lawrence River AOC, as beneficial uses must be restored to all 14 BUIs prior

123 to delisting (International Joint Commission, 2012), including reductions in symptoms of

124 eutrophication and the presence of undesirable algae.

\section{Methods}

126 Study Area

127 The St. Lawrence River at Cornwall, Ontario, Canada, marks the eastern end of the

128 international section of the waterway and is located just downstream of the Moses-Saunders

129 Power Dam. East of the city of Cornwall, the river widens into Lake St. Francis for $50 \mathrm{~km}$ before

130 narrowing again as it passes around Grande-Île, near Salaberry-de-Valleyfield, Quebec (Fig. 1a).

131 Lake St. Francis covers approximately $233 \mathrm{~km}^{2}$, with a mean depth of $6 \mathrm{~m}$ (maximum $26 \mathrm{~m}$ ),

132 short hydraulic residence time (3 days) and a total volume of $2.8 \mathrm{~km}^{3}$ (Anderson et al., 1992;

133 Fortin et al., 1994). Water level is controlled in this portion of the St. Lawrence River by the

134 Moses-Saunders Power Dam upstream and the Coteau works and Beauharnois hydroelectric 
135 generating station downstream (Anderson et al., 1992). Water levels in the St. Lawrence River

136 are regulated by the International Joint Commission to stabilise Lake Ontario and to ensure

137 adequate capacity for navigation, hydroelectric power generation, and flood control (Yee et al.,

138 1990). In LSF, Hydro Quebec manages the downstream discharge through the Beauharnois dam

139 such that water level variation is typically $<20 \mathrm{~cm}$ (Morin and Leclerc, 1998). Approximately

$14095 \%$ of the flow in LSF comes from Lake Ontario, with the remainder originating from

141 tributaries on the north and south shores (Anderson et al., 1992). Little mixing occurs across the

142 main shipping channel, which divides the north and south portions of LSF, each of which is

143 differently influenced by local inflow tributaries (International Joint Commission, 2003b). As a

144 result, the main channel and the flows north and south thereof can be considered to be three

145 distinct water bodies (Dreier et al., 1997). On the northern shore, nine Ontario watersheds drain

146 into LSF, the largest of which, the Raisin River watershed, covers over $500 \mathrm{~km}^{2}$ (Fig. 1b, c).

147 Across the northern watersheds, the dominant agricultural products are corn and soybeans,

148 accounting for $15 \%$ and $14 \%$ of land use, respectively, with other dominant land cover including

149 forest (43\%), pasture and forages (15\%), and urban and developed areas (8\%; 2015 annual crop

150 inventory data from Agriculture and Agri-Food Canada,

151 http://open.canada.ca/data/en/dataset/3688e7d9-7520-42bd-a3eb-8854b685fef3, accessed 25

152 July, 2017).

153 In the deep, fast-flowing channels of the river, sedimentation does not reliably occur

154 (Carignan and Lorrain, 2000), making the collection of a sediment core representative of past

155 conditions unlikely from deeper sites. Several areas in LSF also have been disturbed previously

156 by dredging activities when the shipping channel was created as part of the construction of the

157 St. Lawrence Seaway in the 1950s (Morin and Leclerc, 1998); such areas were avoided for the 
158 current study to ensure a continuous, undisturbed sedimentary record. In the AOC, five

159 sedimentation basins have been described (Lorrain et al., 1993), two of which are on the northern

160 side of the main channel of the St. Lawrence River and are likely to be influenced by flows from

161 the northern tributaries. Sediment cores with reliable, continuous dating profiles have previously

162 been collected from both of these basins (Carignan and Lorrain, 2000). The more westerly of

163 these two basins, located just east of Lancaster, Ontario, is in a portion of the river that has seen

164 extensive water-quality monitoring take place since 2010 (Bramburger, 2014; Savard et al.,

$1652013,2015)$. Both the availability of recent monitoring data and the known sedimentation

166 characteristics of the basin influenced the selection of this site for sample collection.

167 Sediment Collection

168 A sediment core was collected on May 5, 2016 from the St. Lawrence River near

169 Lancaster, Ontario, Canada $\left(74^{\circ} 27^{\prime} 47^{\prime \prime} \mathrm{W}, 45^{\circ} 08^{\prime} 07^{\prime \prime} \mathrm{N}\right.$; Fig. $\left.1 \mathrm{~b}\right)$ using a modified gravity corer

170 (Glew, 1989) with an internal diameter of $7.62 \mathrm{~cm}$. The collection site was located

171 approximately $900 \mathrm{~m}$ from shore, $2.5 \mathrm{~km}$ downstream from the outlet of the Raisin River (Fig.

172 1b). The core was collected from a depth of $5 \mathrm{~m}$ to minimise sediment mixing (Carignan and

173 Lorrain, 2000; Lepage et al., 2000). Additionally, this location was selected for sample

174 collection to best achieve proximity to tributary inputs while remaining deep enough to

175 experience permanent sediment deposition without resuspension.

176 The collected core was sectioned in the field into $0.5-\mathrm{cm}$ increments which were bagged,

177 transported in the dark to Queen's University, and stored in the dark at $\sim 4^{\circ} \mathrm{C}$ until analysis.

178 Subsamples were taken for determination of sediment ages using gamma spectroscopy, pigment

179 concentrations using high performance liquid chromatography (HPLC), organic matter content 
180 via loss-on-ignition (LOI), stable isotope analyses using mass spectrometry, and diatom

181 assemblages using light microscopy.

182 Chronology

183 Gamma spectroscopy was used to measure the activities of total ${ }^{210} \mathrm{~Pb},{ }^{214} \mathrm{~Pb}$ and ${ }^{214} \mathrm{Bi}$

184 (proxies of supported ${ }^{210} \mathrm{~Pb}$ ), and ${ }^{137} \mathrm{Cs}$ following the methods of Schelske et al. (1994) in 25

185 intervals throughout the core. Sediments were freeze-dried, then approximately $1 \mathrm{~g}$ dry mass was

186 sealed into counting tubes using 2-Ton ${ }^{\circledR}$ Epoxy. Samples were left for 2 weeks for in situ decay

187 of ${ }^{226} \mathrm{Ra}$ to stabilise. The constant rate of supply (CRS) calculation of Appleby and Oldfield

188 (1978) was used to estimate sediment ages using unsupported ${ }^{210} \mathrm{~Pb}$ activity in conjunction with

$189{ }^{137}$ Cs activity, an independent indicator of the year 1963 (Appleby, 2002).

190 Pigments

$191 \quad$ Frozen subsamples of whole sediments were taken for determination of photosynthetic

192 pigment concentrations from 37 intervals throughout the core. Pigments were extracted and

193 quantified using high performance liquid chromatography (HPLC) following the protocol

194 outlined in Leavitt and Hodgson (2001). Briefly, frozen samples were freeze-dried, and

195 approximately $0.05 \mathrm{~g}$ of dried sediment was extracted using a mixture of acetone:methanol:water

196 (80:15:5, by volume) to extract chlorophylls, carotenoids, and their derivatives. Extracts were

197 evaporated to dryness under a stream of $\mathrm{N}_{2}$, then redissolved in injection solvent containing

198 Sudan II dye as an internal standard. Pigment concentrations are reported as nmoles pigment/g

199 organic matter. HPLC analyses were restricted to common taxonomically-diagnostic pigments

200 including fucoxanthin (siliceous algae), diatoxanthin (mainly diatoms), alloxanthin

201 (cryptophytes), phaeophytin $b$ (chlorophytes), echinenone (total cyanobacteria), canthaxanthin

202 (Nostocales cyanobacteria), and $\beta$-carotene (all phytoplankton). In addition, lutein (chlorophytes) 
203 and zeaxanthin (cyanobacteria) were not separable on our HPLC system and were used as an

204 index of bloom-forming taxa (Leavitt et al., 2006; Leavitt and Hodgson, 2001).

Organic Matter and Stable Isotopes

Percent organic matter was determined through standard LOI procedures (Dean, 1974) in

20725 intervals throughout the sediment core. Briefly, a known mass ( $\sim 0.08 \mathrm{~g})$ of freeze-dried

208 sediment was tared and combusted at $550^{\circ} \mathrm{C}$ for 4 hours to determine organic content, then

209 ignited at $950^{\circ} \mathrm{C}$ for 2 hours to determine carbonate content. Stable isotopes of $\mathrm{N}\left(\delta^{15} \mathrm{~N}\right)$ and $\mathrm{C}$

$210\left(\delta^{13} \mathrm{C}\right)$, as well as elemental $\mathrm{N}$ and $\mathrm{C}$ contents, were determined using isotope ratio mass

211 spectrometric (IRMS) analysis of 0.01-0.015 $\mathrm{g}$ of freeze-dried sediment following Savage et al.

212 (2010). IRMS was performed using a Thermoquest (Finnigan-MAT) Delta Plus ${ }^{\mathrm{XL}}$ mass

213 spectrometer coupled with a Carlo Erba NC2500 elemental analyser (Savage et al., 2010).

214 Isotope values are presented as per mille (\%) differences of samples to standard references for

215 each element (Savage et al., 2010). Sediment elemental composition is reported as the mass ratio

216 of $\mathrm{C}: \mathrm{N}$, as determined through the elemental analyser.

217 Diatoms

218 Diatom slurries were prepared for enumeration after removal of organic matter using an

219 acid digestion procedure. Briefly, approximately $0.2-0.3 \mathrm{~g}$ of whole wet sediment was

220 subsampled at $1-\mathrm{cm}$ intervals into 20 -mL glass scintillation vials. Known masses of sediment

221 were mixed with a 50:50 (molar) solution of sulphuric and nitric acids overnight, then digested in

222 a hot water bath at $70^{\circ} \mathrm{C}$ for 8 hours. Diatoms were allowed to settle for 24 hours, after which the

223 supernatant above the settled diatoms was aspirated. Scintillation vials were then refilled with

224 double-deionised water, and samples were agitated to resuspend the diatoms. Samples were

225 rinsed until the $\mathrm{pH}$ was the same as deionised water, as verified with litmus paper (typically eight 
226 rinses). Samples were then spiked with a solution of microspheres (mean diameter $=7.9 \mu \mathrm{m})$ of

227 known concentration (34,000 microspheres/mL). Samples were plated on coverslips in a series of

228 four dilutions and allowed to evaporate, after which they were fixed permanently to slides using

229 Naphrax $^{\circledR}$, a medium with a high refractive index $(>1.7)$.

230 Diatom valves were identified and enumerated using a Leica (DMRB model) microscope

231 fitted with a 100x fluotar objective (numerical aperture of objective $=1.3$ ) and using differential

232 interference contrast optics at 1000x magnification. Diatoms were identified to species wherever

233 possible, or to the lowest possible taxonomic classification. Valves were counted until a

234 minimum of 400 valves were enumerated, or, if the concentration of valves was exceptionally

235 low, until five transects were completed. Primary taxonomic keys used for diatom identification

236 were Krammer and Lange-Bertalot (1991a, 1991b, 1988, 1986) and Reavie and Smol (1998).

237 The main chronological zones of diatom species assemblages were estimated using a

238 constrained incremental sum of squares analysis (CONISS; Grimm, 1987), performed in the R

239 computing environment (R Core Team, 2015) and the rioja (Juggins, 2015) and vegan (Oksanen

240 et al., 2015) packages. Diatom abundances were Hellinger-transformed (Rao, 1995) prior to

241 CONISS analysis using Euclidean distance, to minimise distortions that can occur when zero

242 values are present (Legendre and Legendre, 2012). A broken stick model (Bennett, 1996) was

243 used to determine the number of significant zones in the stratigraphic sequence.

\section{Results}

\section{Chronology}

The total ${ }^{210} \mathrm{~Pb}$ activity decreased from the top of the sediment core and followed an

247 exponential decay $\left(r^{2}=0.83\right.$; Fig. 2). Both ${ }^{214} \mathrm{~Pb}$ and ${ }^{214} \mathrm{Bi}$ activities remained relatively constant

248 throughout the core, and are consistent with previously collected sediment cores from LSF which 
249 have reported supported ${ }^{210} \mathrm{~Pb}$ activities of approximately $20 \mathrm{~Bq} / \mathrm{kg}$ (Carignan and Lorrain, 250 2000). ${ }^{137} \mathrm{Cs}$ activity reached a distinct peak at a depth of $18.25 \mathrm{~cm}$.

251 Application of the CRS model to determine sediment ages and sedimentation rates from

252 the unsupported ${ }^{210} \mathrm{~Pb}$ activities suggested that dates were reliable until approximately $30-\mathrm{cm}$

253 burial depth (ca. 1940; Fig. 2). Although local error estimates are large, sedimentation rates

254 appear to have increased substantially between depths of approximately 25 and $20 \mathrm{~cm}$ (1955-

$2551959)$ in the core. The depth at which the year 1963 occurred was agreed-upon by the ${ }^{210} \mathrm{~Pb}$

256 model and the analysis of ${ }^{137} \mathrm{Cs}$ activity $(\sim 18 \mathrm{~cm})$. Given this dating profile, approximate depths

257 in the core for the designation of the AOC (1987) and the release of the Stage 1 (1992) and Stage

2582 (1997) RAP reports are $9.75 \mathrm{~cm}, 8.75 \mathrm{~cm}$, and $7.25 \mathrm{~cm}$, respectively.

259 Pigments

260 Analysis of concentrations of all pigment biomarkers suggested a progressive increase in

261 lake production during the $20^{\text {th }}$ century (Fig. 3). In general, total phytoplankton abundance (as $\beta$ -

262 carotene) was stable from the base of the core to ca. 1960, after which time inferred abundance

263 increased approximately twofold to an irregular plateau after ca. 1980. As ratios of labile to

264 stable pigments (chlorophyll $a$ :phaeophytin $a$ ) did not change in the ca. 1960-1980 interval, we

265 infer that elevated concentrations of pigments reflect actual increases in mean water column

266 standing stock, rather than alterations in the preservation environment. Although timing of the

267 concentration change varies slightly among algal groups, concentrations of chemically-stable

268 biomarkers from total (echinenone) and colonial cyanobacteria (canthaxanthin), chlorophytes

269 (phaeophytin $b$ ), diatoms (diatoxanthin) and cryptophytes (alloxanthin) all exhibited similar

270 patterns, with elevated abundance of these groups after the mid-1970s. In contrast, levels of

271 labile pigments from siliceous (fucoxanthin) and total algae (chlorophyll $a$ ) declined 
272 exponentially with burial depth, suggesting rapid degradation following deposition, especially in

273 the most recent 5 years. Finally, concentrations of many chemically-stable pigments increased

274 sharply after ca. 2005, suggesting a recent increase in either algal abundance or changes in

275 sedimentary preservation.

276 Organic Matter and Stable Isotopes

277 The organic matter content remained relatively constant throughout the core, varying

278 between $8 \%$ and $13 \%$ of dry mass (Fig. 4). In contrast, $\delta^{15} \mathrm{~N}$ values were stable ( 5\%o) from the

279 bottom of the core until the early 1960s ( 20-cm depth) and then increased steadily towards $7 \%$ o

280 at the top of the core, in a pattern similar to the changes in total algal abundance (Fig. 3). The

$281 \quad \delta^{13} \mathrm{C}$ values increased rapidly from approximately $-23 \%$ at $\sim 30$-cm depth (early $20^{\text {th }}$ century) to -

$28216 \%$ at $25 \mathrm{~cm}$ (ca. early 1950s), before declining to consistent values of approximately $-20 \%$ in

283 sediments deposited in the upper $20 \mathrm{~cm}$ of the core (after 1960; Fig. 4). The C:N mass ratio

284 followed a similar trajectory to that of $\delta^{13} \mathrm{C}$, starting at approximately 15 at the base of the core,

285 increasing to 23 at a depth of $25 \mathrm{~cm}$ (ca. 1960), then gradually decreasing until the top of the

286 core where it reached a value of 10 (Fig. 4).

287 Diatoms

288 Concentrations of diatoms increased exponentially from $\sim 1 \times 10^{5}$ valves/g dry mass prior

289 to ca. 1960 to greater than 4 x $10^{6}$ valves/g dry mass in surface deposits (Fig. 5). After ca. 1970,

290 diatom concentrations increased in a pattern moderately correlated $\left(\mathrm{r}^{2}=0.57, p<0.001\right)$ with

291 fossil concentrations of the labile biomarker of siliceous algae (fucoxanthin). Constrained cluster

292 analysis using CONISS distinguished two main zones of diatom species assemblages, which

293 appear to correspond to intervals before and after construction of the Moses-Saunders Power

294 Dam (1954-1959; 23.25-cm depth). The older assemblage was characterised by higher 
abundances of Fragilaria construens (Ehrenberg) Grunow, Sellaphora submuralis (Hustedt)

296 Wetzel, Ector, Van de Vijver, Compère, \& Mann, Achnanthes clevei Grunow, and Cocconeis

297 neothumensis Krammer. Above $23.25 \mathrm{~cm}$, several taxa became much more prevalent, including

298 Achnanthidium minutissimum (Kützing) Czarnecki, F. capucina Desmazières, C. placentula

299 (Ehrenberg) Grunow, Navicula cryptotenella Lange-Bertalot, and Nitzschia fonticola Grunow.

300 Other taxa, such as Amphora pediculus (Kützing) Grunow ex Schmidt, Staurosirella pinnata

301 (Ehrenberg) Williams \& Round, Pseudostaurosira brevistriata (Grunow) Williams \& Round,

302 and Planothidium lanceolatum (Brébisson ex Kützing) Lange-Bertalot, were present in relatively

303 high abundances throughout the core. Diatoms identified were predominantly benthic taxa.

\section{Discussion}

Analyses of fossil pigments, diatoms, and stable isotopes revealed a progressive increase

306 in the abundance of primary producers in this portion of LSF during the late- $20^{\text {th }}$ century,

307 continuing into the $21^{\text {st }}$ century (Figs. 3-5). In general, algal abundance and community

308 composition were relatively stable prior to the 1954-1959 construction of the Moses-Saunders

309 Power Dam and the St. Lawrence Seaway, with low and constant concentrations of biomarker

310 pigments from diatoms (diatoxanthin) and chlorophytes (phaeophytin $b$, lutein-zeaxanthin), and

311 lower abundances of total (echinenone) and colonial (canthaxanthin) cyanobacteria. Diatom

312 assemblage composition changed after dam construction (ca. 1960), though assemblages before

313 and after this period were both characterised by benthic taxa, none of which indicated a change

314 to LSF trophic status. Total algal abundance appears to have increased after ca. 1970, with an

315 approximate two-fold increase in fossil concentrations of most pigment biomarkers (Fig. 3), but

316 no marked change in the preservation environment, as recorded by the degradation index of

317 labile chlorophyll $a$ to stable phaeophytin $a$ (Leavitt and Hodgson, 2001). This increase in 
318 abundance occurs in parallel with elevated nutrient supply inferred from the $\delta^{15} \mathrm{~N}$ signal (Fig. 4).

319 Microfossil and labile pigments from diatoms were particularly abundant after ca. 2005, as were

320 concentrations of chemically stable carotenoids from total cyanobacteria (echinenone, lutein-

321 zeaxanthin) and cryptophytes (alloxanthin) but not those from chlorophytes (phaeophytin $b$ ) or

322 total algae ( $\beta$-carotene). Overall, this pattern shows that water quality along the north shore of

323 LSF did not improve as a result of local and regional remedial actions implemented in the early

324 1990s and suggests that substantial additional measures to curb nutrient influxes from regional

325 and headwater sources are required if the AOC delisting goals relating to eutrophication and

326 undesirable algae are to be achieved.

327 Baseline Conditions (pre-1950s)

Prior to the construction of the Moses-Saunders Power Dam and the St. Lawrence

329 Seaway in the mid-1950s, conditions were stable, with relatively constant concentrations of most

330 photosynthetic pigments, low and steady concentrations of diatoms, and diatom assemblages

331 characterised by predominantly benthic taxa. Organic material in the aquatic environment was

332 supplied by both autochthonous and allochthonous sources, as indicated by the moderate and

333 stable molar ratio of C:N (Meyers and Ishiwatari, 1993; Fig. 4). An exact chronology is difficult

334 to assign to this portion of the sediment core, as errors associated with sediment dating are large

335 (Fig. 2); however, we are confident that the bottom four intervals represent a period of time prior

336 to the 1950s. Although we cannot consider these records to represent pristine conditions, as

337 industrial activity had been occurring upstream of our site in Cornwall, Ontario, since the late-

$33819^{\text {th }}$ century (Stein, 1995), we will refer to them as baseline conditions which represent a period

339 prior to the major anthropogenic changes that occurred in our system during the second half of

340 the $20^{\text {th }}$ century. 
Between 1954 and 1959, two major construction projects occurred in this portion of the

343 St. Lawrence River: the construction of the Moses-Saunders Power Dam and the dredging of the

344 St. Lawrence Seaway. These concurrent events appear to be represented in our paleolimnological

345 record through marked changes in $\delta^{13} \mathrm{C}$ values and $\mathrm{C}: \mathrm{N}$ ratios, as well as diatom species

346 composition. For example, although the $\delta^{15} \mathrm{~N}$ values remained relatively stable through the

347 1950s, the C:N ratio increased quickly at this time, indicating a substantial increase in the

348 terrestrial fraction of organic matter entering the system (Meyers and Ishiwatari, 1993). At the

349 same time, a sharp increase in the $\delta^{13} \mathrm{C}$ signal (Fig. 4) to values characteristic of regional

350 terrestrial plants suggests an increase in organic matter subsidies from adjacent farms (Meyers

351 and Ishiwatari, 1993). Elevated influxes of terrestrial organic matter most likely arose from the

352 construction of the Moses-Saunders Power Dam, which flooded more than $75 \mathrm{~km}^{2}$ of land, much

353 of it agricultural, on July 1, 1958 (Macfarlane, 2014). High sedimentary $\delta^{13} \mathrm{C}$ values in the $1950 \mathrm{~s}$

354 may be additionally driven by an elevated proportion of C4 plants such as corn in the watershed.

355 At present, corn is a predominant crop within the local catchment area (2015 annual crop

356 inventory data from Agriculture and Agri-Food Canada,

357 http://open.canada.ca/data/en/dataset/3688e7d9-7520-42bd-a3eb-8854b685fef3, accessed 25

358 July, 2017), although we recognise that it is difficult to distinguish among potential plant sources

359 of $\mathrm{C}$ from an analysis of bulk sediment isotopic values.

360 Analysis of the fossil diatom assemblages using stratigraphically constrained hierarchical

361 cluster analysis revealed only a single transition in species assemblages, which occurred in the

362 late-1950s, coinciding with the construction of the Moses-Saunders Power Dam and the St.

363 Lawrence Seaway (Fig. 5). Previous research at the eastern end of LSF has suggested that an 
364 increase in epiphytic diatom taxa and inferred higher macrophyte coverage occurred in the early365 to mid- $20^{\text {th }}$ century, possibly attributable to a decrease in the variability of the water level

366 resulting from Seaway construction and the construction of water control structures at the eastern

367 end of LSF (Reavie et al., 1998). Seasonal water level variability in LSF was known to exceed

$3680.5 \mathrm{~m}$ in the first half of the $20^{\text {th }}$ century, but this variability was reduced to less than $0.2 \mathrm{~m}$ after

369 the construction of the Moses-Saunders Power Dam (Morin and Leclerc, 1998). Although some

370 epiphytic diatom taxa (e.g., Cocconeis placentula) were observed in the current study to be more

371 abundant after the construction of the Moses-Saunders Power Dam, possibly attributable to

372 higher macrophyte coverage due to stabilisation of water levels, many of the diatom taxa that

373 were abundant following dam construction (e.g., Fragilaria capucina, Amphora pediculus) can

374 be commonly found on other substrata (e.g., rocks; Reavie and Smol, 1997). The diatom

375 assemblages before and after the late-1950s share many characteristics, such as being

376 predominantly benthic taxa with no strong trophic status affiliations, with some epiphytic taxa

377 present. It seems likely that the two major construction projects in the St. Lawrence River in the

378 1950s caused a substantial disturbance to the aquatic environment (as indicated by the abrupt

379 terrestrial loading suggested by the $\mathrm{C}: \mathrm{N}$ ratio), which allowed a slightly different diatom

380 assemblage to settle and thrive once the disturbance was over.

$20^{\text {th }}$ Century Eutrophication (1960s-1970s)

In the 1960s and 1970s, the lower Laurentian Great Lakes were characterised by

383 intensive eutrophication and related algal blooms and hypoxia (Beeton, 1965; Mortimer, 1987;

384 Schelske, 1991), events which are represented in our core by increases in photosynthetic

385 pigments and diatoms. The pigment data suggest that production increased first in the early- to

386 mid-1970s, indicated particularly by biomarkers derived from bloom-forming cyanobacteria 
387 (canthaxanthin), chlorophytes (phaeophytin $b$ ), diatoms (diatoxanthin), and total production ( $\beta$ -

388 carotene). This trend is supported by an increase in diatom production between the early-1960s

389 and 1970s, during which a 4-fold increase in fossil frustule concentration occurred, and a

390 previously reported mid- $20^{\text {th }}$ century increase in eutrophic diatom taxa at the eastern end of LSF

391 (Reavie et al., 1998). At present, we cannot easily distinguish between elevated production in

392 LSF due to inputs of nutrient- and phytoplankton-rich waters from the upstream Great Lakes,

393 and elevated production due to eutrophication of the LSF basin from local nutrient influx, as

394 historical surface water-quality monitoring data are limited. However, nutrient monitoring of the

395 Raisin River, a major tributary near the sampling location of the current study, indicates that,

396 after 1976, high (>30 $\mu \mathrm{g} / \mathrm{L}$ ) and variable TP concentrations have occurred (data from Ontario

397 Ministry of the Environment and Climate Change, https://www.ontario.ca/data/provincial-

398 stream-water-quality-monitoring-network, site 12007300302, accessed 19 December, 2016).

399 N influx to LSF appears to have increased markedly during the 1960s and 1970s, as

400 indicated by persistent increases in sedimentary $\delta^{15} \mathrm{~N}$ values (Fig. 4). As noted elsewhere

401 (Leavitt et al., 2006; Savage et al., 2010; Bunting et al., 2016), the addition of anthropogenic

402 reactive $\mathrm{N}$ to terrestrial and aquatic systems often results in the enrichment of adjoining water

403 bodies due to microbial processing of added $\mathrm{N}$ and loss of depleted $\mathrm{N}$ to the atmosphere.

404 Similarly, the values of $\delta^{15} \mathrm{~N}$ in aquatic food webs (Anderson and Cabana, 2005) and stream

405 nitrate (Harrington et al., 1998) have been positively correlated with agricultural land use in the

406 surrounding catchment. Consistent with this mechanism, the sharp increase in fertilisation of

407 Ontario farmlands with $\mathrm{N}$ between the 1960s and 1980s (Smith, 2015) is expected to have

408 favoured the elevation of both flux and isotopic values of N in runoff into the St. Lawrence

409 River. 
Since the designation of the St. Lawrence River at Cornwall, Ontario, as an AOC,

412 remediation efforts have successfully targeted many of the BUIs. For example, water quality has

413 improved through upgrades to the Cornwall wastewater treatment plant, remediation of

414 decommissioned industrial sites (e.g., chemical manufacturing facilities), and legislation

415 restricting concentrations of harmful substances in wastewater effluent from industrial facilities

416 (Environment Canada et al., 2007; Environment Canada and Ontario Ministry of the

417 Environment, 2010). Similarly, progress has been made on improving fish and wildlife

418 biodiversity and condition through wetland construction, habitat protection programs, and

419 changes to fishing regulations (Environment Canada et al., 2007). As well, many remedial

420 actions in the AOC have targeted the issue of eutrophication and undesirable algae. For example,

421 a tributary restoration program initiated in 1994 has led to the planting of over 300,000 trees in

422 riparian areas, increased buffer zones and cattle exclusion fencing along waterways, upgraded

423 manure storage facilities and rural septic systems, increased well protection projects, and more

424 (Environment Canada et al., 2007). However, despite these efforts, our data suggest that the

425 eutrophication and undesirable algae BUI remains impaired, with continuously elevated algal

426 abundance (as pigment and diatom concentrations) since the 1990s and no evidence of recovery

427 to lower abundances.

428 Pronounced increases in sedimentary pigment content during the past 10 years were

429 observed for echinenone, a chemically stable biomarker for total cyanobacteria (Leavitt and

430 Hodgson, 2001), and are consistent with increased reports of potentially toxic cyanobacteria in

431 recent years (Bramburger, 2014; Savard et al., 2013, 2015). Elevated cyanobacterial abundance

432 could be attributable to several factors, including high nutrient concentrations (Downing et al., 
433 2001); although lotic TP concentrations from the Raisin River have not increased in recent years,

434 values have remained persistently high (> $30 \mu \mathrm{g} / \mathrm{L}$ ) since the early-1990s (data from Ontario

435 Ministry of the Environment and Climate Change, https://www.ontario.ca/data/provincial-

436 stream-water-quality-monitoring-network, site 12007300302, accessed 19 December, 2016), and

437 similarly high TP concentrations have been reported in the nearshore areas of tributary mouths

438 (Savard et al., 2015). Given these consistently high TP values and the evidence of persistent

439 increases in sedimentary nutrient influx in LSF $\left(\delta^{15} \mathrm{~N}\right.$ in Fig. 4), it appears likely that recent

440 cyanobacterial growth has been influenced by nutrient inputs. Upstream of our study location,

441 surface-water chlorophyll $a$ concentrations collected at Kingston and Brockville have dropped

442 substantially since the 1980 s, from approximately $2-5 \mu \mathrm{g} / \mathrm{L}$ to $<1 \mu \mathrm{g} / \mathrm{L}$ (data from Ministry of

443 the Environment and Climate Change, https://www.ontario.ca/data/lake-water-quality-drinking-

444 water-intakes, stations 020170010 and 020180011 , accessed 3 September 2017), suggesting that

445 production has not increased in the main river channel flowing into LSF and supporting local

446 nutrient inputs as an influence to cyanobacterial growth. In general, modelling of nutrient fluxes

447 in St. Lawrence River catchments shows that net anthropogenic inputs of nitrogen and

448 phosphorus have increased throughout the $20^{\text {th }}$ century, with pronounced effects of agricultural

449 fertilisers during the past 50 years (Goyette et al., 2016), which may be particularly relevant

450 given the high proportion of agricultural lands in the contributing watersheds to our study site

451 (Fig. 1c). Unfortunately, without refined hydrologic models of water flow in the LSF nearshore

452 region, it is difficult to identify which catchments may be fertilising waters in the AOC. In

453 particular, combining flow modelling with nutrient modelling (Goyette et al., 2016) might allow

454 for the determination of priority areas for nutrient monitoring in the LSF nearshore. 
It is possible that other factors have also affected the recent cyanobacterial growth in our

456 study area, though these influences are difficult to assess without in-depth analyses. Recently,

457 persistent eutrophication issues have been described in areas where monitoring data suggest that

458 nutrient concentrations have declined (Alexson et al., 2017), which may be explained in lakes by

459 hypoxia-induced internal phosphorus loading resulting from stronger thermal stratification

460 related to climate change (North et al., 2014). Although it is unlikely that internal phosphorus

461 loading is providing an additional source of nutrients at our shallow, well-oxygenated, fluvial

462 site, hydrologic changes relating to catchment land use and climate change may have altered

463 nutrient delivery to LSF. For instance, pronounced land-use changes in the Raisin River

464 watershed have occurred between 1990 and 2010, with urban areas increasing by $12 \%$ and the

465 extent of treed and forested areas decreasing by $20 \%$ (data from Agriculture and Agri-Food

466 Canada, http://open.canada.ca/data/en/dataset/02202cec-b4a1-4a1d-9997-edcbaca92d41,

467 http://open.canada.ca/data/en/dataset/9e1efe92-e5a3-4f70-b313-68fb1283eadf, accessed 3

468 September, 2017). Although land use devoted to crops in this watershed has only increased by

$4690.5 \%$, deforestation and urbanisation could have increased runoff (Hundecha and Bárdossy,

470 2004), facilitating the transport of nutrients from the watershed to LSF. Climate change may

471 have also favoured the proliferation of cyanobacteria, either directly (i.e., increased water

472 temperatures; Paerl and Huisman, 2008) or indirectly (e.g., increased frequency of droughts and

473 floods; Paerl et al., 2011). Temperature and precipitation trends in the Great Lakes-St. Lawrence

474 River Basin have climbed throughout the $20^{\text {th }}$ century (Magnuson et al., 1997), and temperature

475 increases and hydrologic changes are expected to continue to occur in St. Lawrence River

476 tributaries throughout the $21^{\text {st }}$ century, particularly in the winter and spring months (Boyer et al.,

477 2010). Though it is impossible to assess the influences of land-use change and climate change on 
478 cyanobacterial abundance within the confines of the current study, it is unlikely that these factors

479 have not affected cyanobacterial growth and should be more thoroughly investigated.

\section{Conclusion}

Though numerous actions have targeted reducing nutrient inputs to LSF in the past 20

482 years, we found that algal abundance has not decreased in response to remediation efforts, and

483 that, in fact, populations of cyanobacteria appear to have expanded during the past decade. The

484 causal mechanism for this increase in not immediately clear, but is likely related to continuously

485 high nutrient concentrations in major LSF tributaries, possibly combined with major land-use

486 changes and climate change. The potential for toxin-producing cyanobacterial blooms is

487 particularly troubling for both local and downstream residents, and the cyanobacterial

488 communities of LSF and its tributaries should be monitored closely for the presence of

489 potentially toxin-producing species. As the AOC committee works toward delisting, it is

490 important to recognise that, despite successes in other areas, the sediment record demonstrates

491 continuing impacts to water quality in LSF over the past two decades, indicating that the

492 eutrophication and undesirable algae BUI remains in need of remediation.

\section{Acknowledgements}

This project received financial support from an NSERC IPS scholarship to KEM,

495 supported by the St. Lawrence River Institute of Environmental Sciences. PRL was supported by

496 an NSERC Discovery Grant, the Canada Research Chairs organisation, Canada Foundation for

497 Innovation, Province of Saskatchewan, and University of Regina. The authors would like to

498 acknowledge MacKenzie Waller and Sasha Laird for field assistance and Deirdre Bateson for

499 HPLC pigment analyses. 
AECOM Canada Ltd., 2009. Evaluation of remedial action plan tributary nutrient delisting criteria for the St. Lawrence River, Cornwall, Area of Concern. Bracebridge, ON.

Agriculture and Agri-Food Canada, 2016. Annual Crop Inventory 2015 - Open Government License - Canada.

Anderson, C., Cabana, G., 2005. $\delta 15 \mathrm{~N}$ in riverine food webs: effects of $\mathrm{N}$ inputs from

Alexson, E.E., Reavie, E.D., Axler, R.P., Yemets, S.V., Krasutsky, P.A., Edlund, M.B., Pillsbury, R.W., Desotelle, D., 2017. Paleolimnology of a freshwater estuary to inform Area of Concern nutrient delisting efforts. J. Paleolimnol. https://doi.org/ Milnes, J., Pritchard, K., Richman, L., 1992. Remedial action plan for the St. Lawrence River (Cornwall) area of concern. Stage 1 report: environmental conditions and problem definitions.

Appleby, P.G., 2002. Chronostratigraphic techniques in recent sediments, in: Last, W.M., Smol, J.P. (Eds.), Tracking Environmental Change Using Lake Sediments, Developments in Paleoenvironmental Research. Springer Netherlands, pp. 171-203. https://doi.org/10.1007/0-306-47669-X_9

Appleby, P.G., Oldfield, F., 1978. The calculation of lead-210 dates assuming a constant rate of supply of unsupported $210 \mathrm{~Pb}$ to the sediment. Catena $5,1-8$. https://doi.org/10.1016/S0341-8162(78)80002-2 
Battarbee, R.W., Jones, V.J., Flower, R.J., Cameron, N.G., Bennion, H., Carvalho, L., Juggins, S., 2002. Diatoms, in: Smol, J.P., Birks, H.J.B., Last, W.M., Bradley, R.S., Alverson, K. (Eds.), Tracking Environmental Change Using Lake Sediments, Developments in Paleoenvironmental Research. Springer Netherlands, pp. 155-202. https://doi.org/10.1007/0-306-47668-1_8

Beeton, A.M., 1965. Eutrophication of the St. Lawrence Great Lakes. Limnol. Oceanogr. 10, $240-254$.

Bennett, K.D., 1996. Determination of the number of zones in a biostratigraphical sequence. New Phytol. 132, 155-170.

Boyer, C., Chaumont, D., Chartier, I., Roy, A.G., 2010. Impact of climate change on the hydrology of St. Lawrence tributaries. J. Hydrol. 384, 65-83. https://doi.org/10.1016/j.jhydrol.2010.01.011

Bramburger, A.J., 2014. Transport and differential influences of phosphorus fractions on algal community dynamics in the nearshore zone of Lake St. Francis, St. Lawrence River. Prepared by the SLRIES for the Ontario Ministry of the Environment and Climate Change.

Bunting, L., Leavitt, P.R., Simpson, G.L., Wissel, B., Laird, K.R., Cumming, B.F., St. Amand, A., Engstrom, D.R., 2016. Increased variability and sudden ecosystem state change in Lake Winnipeg, Canada, caused by 20th century agriculture. Limnol. Oceanogr. 61, 2090-2107. https://doi.org/10.1002/lno.10355

Carignan, R., Lorrain, S., 2000. Sediment dynamics in the fluvial lakes of the St. Lawrence River: accumulation rates and characterization of the mixed sediment layer. Can. J. Fish. Aquat. Sci. 57, 63-77. https://doi.org/10.1139/f99-246 
545 Carmichael, W.W., 2001. Health effects of toxin-producing cyanobacteria: "The CyanoHABs."

546 Hum. Ecol. Risk Assess. Int. J. 7, 1393-1407. https://doi.org/10.1080/20018091095087

547 Dean, W.E.J., 1974. Determination of carbonate and organic matter in calcareous sediments and

548 sedimentary rocks by loss on ignition: comparison with other methods. J. Sediment. Res. 44, 242-248. https://doi.org/https://doi.org/10.1306/74D729D2-2B21-11D7-

551 Dixit, A.S., Dixit, S.S., Smol, J.P., Keller, W.B., 1998. Paleolimnological study of metal and nutrient changes in Spanish Harbour, north channel of Lake Huron (Ontario). Lake Reserv. Manage. 14, 428-439. https://doi.org/10.1080/07438149809354349

Dreier, S.I., Anderson, J., Biberhofer, J., Eckersley, M., Helliar, R., Hickey, M.B.C., Richman, L., Stride, F., 1997. Remedial action plan for St. Lawrence River (Cornwall) area of

Downing, J.A., Watson, S.B., McCauley, E., 2001. Predicting cyanobacteria dominance in lakes. concern. Stage 2 report: The recommended plan.

Environment Canada, Ontario Ministry of the Environment, 2010. St. Lawrence River area of concern (Canadian Section): status of beneficial use impairments.

Environment Canada, Ontario Ministry of the Environment, Ontario Minstry of Natural update to the stage 2 report for the St. Lawrence River (Cornwall) remedial action plan. et chimiques de l'eau et des sediments du Lac Saint-Francois: Rapport technique, zones d'intervention prioritaire 1 et 2. Centre Saint-Laurent, Environnement Canada - Région du Québec. 
568 Glew, J., 1989. A new trigger mechanism for sediment samplers. J. Paleolimnol. 2, 241-243.

$569 \quad$ https://doi.org/10.1007/BF00195474

570 Goyette, J.-O., Bennett, E.M., Howarth, R.W., Maranger, R., 2016. Changes in anthropogenic nitrogen and phosphorus inputs to the St. Lawrence sub-basin over 110 years and impacts on riverine export. Glob. Biogeochem. Cycles 30, 2016GB005384. https://doi.org/10.1002/2016GB005384

Grimm, E.C., 1987. CONISS: a FORTRAN 77 program for stratigraphically constrained cluster analysis by the method of incremental sum of squares. Comput. Geosci. 13, 13-35. https://doi.org/10.1016/0098-3004(87)90022-7

Hall, R.I., Leavitt, P.R., Quinlan, R., Dixit, A.S., Smol, J.P., 1999. Effects of agriculture, urbanization, and climate on water quality in the northern Great Plains. Limnol. Oceanogr. 44, 739-756.

Harrington, R.R., Kennedy, B.P., Chamberlain, C.P., Blum, J.D., Folt, C.L., 1998. 15N enrichment in agricultural catchments: field patterns and applications to tracking Atlantic

584 Hodell, D.A., Schelske, C.L., 1998. Production, sedimentation, and isotopic composition of 585 salmon (Salmo salar). Chem. Geol. 147, 281-294. https://doi.org/10.1016/S0009organic matter in Lake Ontario. Limnol. Oceanogr. 43, 200-214.

Hundecha, Y., Bárdossy, A., 2004. Modeling of the effect of land use changes on the runoff generation of a river basin through parameter regionalization of a watershed model. J. Hydrol. 292, 281-295. https://doi.org/10.1016/j.jhydrol.2004.01.002 
International Joint Commission, 2012. Revised Great Lakes Water Quality Agreement of 1978 as amended by Protocol signed September $7^{\text {th }}, 2012$. Retrieved June $13^{\text {th }}, 2016$ from http://www.ijc.org/en_/Great_Lakes_Water_Quality.

International Joint Commission, 2003a. Status of restoration activities in Great Lakes areas of concern: a special report.

International Joint Commission, 2003b. St. Lawrence River Area of Concern, Status Assessment. from www.dec.ny.gov/docs/water_pdf/massenarapstat0513.pdf.

Juggins, S., 2015. rioja: Analysis of Quaternary Science Data, R package version (0.9-6). (http://cran.r-project.org/project=rioja).

Krammer, K., Lange-Bertalot, H., 1991b. Bacillariophyceae. 4: Teil: Achnanthaceae, in: Ettl, H., Mitteleuropa, Band 2/4. Stuttgart.

Krammer, K., Lange-Bertalot, H., 1988. Bacillariophyceae. 2: Teil: Bacillariaceae, 
611 Leavitt, P.R., Brock, C.S., Ebel, C., Patoine, A., 2006. Landscape-scale effects of urban nitrogen 612 on a chain of freshwater lakes in central North America. Limnol. Oceanogr. 51, 22622277. https://doi.org/10.4319/lo.2006.51.5.2262

614 Leavitt, P.R., Findlay, D.L., 1994. Comparison of fossil pigments with 20 years of phytoplankton data from eutrophic lake 227, Experimental Lakes Area, Ontario. Can. J. Fish. Aquat. Sci. 51, 2286-2299. https://doi.org/10.1139/f94-232

Leavitt, P.R., Hodgson, D.A., 2001. Sedimentary pigments, in: Smol, J.P., Birks, H.J.B., Last,

Legendre, P., Legendre, L.F.J., 2012. Numerical Ecology. Elsevier.

Lepage, S., Biberhofer, J., Lorrain, S., 2000. Sediment dynamics and the transport of suspended matter in the upstream area of Lake St. Francis. Can. J. Fish. Aquat. Sci. 57, 52-62. https://doi.org/10.1139/f99-238

Lorrain, S., Jarry, V., Guertin, K., 1993. Répartition spatiale et évolution temporelle des biphényles polychlorés et du mercure dans les sédiments du Lac Saint-Francois; 1979Lawrence Seaway. University of British Columbia Press, Vancouver, B.C. 1989.

Macfarlane, D., 2014. Negotiating a River: Canada, the U.S., and the Creation of the St. Fee, E.J., Hall, R.I., Mortsch, L.R., Schindler, D.W., Quinn, F.H., 1997. Potential effects of climate changes on aquatic systems: Laurentian Great lakes and Precambrian shield 
region. Hydrol. Process. 11, 825-871. https://doi.org/10.1002/(SICI)10991085(19970630)11:8<825::AID-HYP509>3.0.CO;2-G

635

636

637

638

639

640

641

642

643

644

645

646

647

648

649

650

651

652

653

654

655

Meyers, P.A., Ishiwatari, R., 1993. Lacustrine organic geochemistry-an overview of indicators of organic matter sources and diagenesis in lake sediments. Org. Geochem. 20, 867-900. https://doi.org/10.1016/0146-6380(93)90100-P

Ministry of the Environment and Climate Change, 2014. Provincial (Stream) Water Quality Monitoring Network [WWW Document]. URL https://www.javacoeapp.lrc.gov.on.ca/geonetwork/srv/en/metadata.show?id=13826 (accessed 12.19.16).

Morin, J., Leclerc, M., 1998. From pristine to present state: hydrology evolution of Lake SaintFrançois, St. Lawrence River. Can. J. Civ. Eng. 25, 864-879. https://doi.org/10.1139/198019

Mortimer, C.H., 1987. Fifty years of physical investigations and related limnological studies on Lake Erie, 1928-1977. J. Great Lakes Res. 13, 407-435.

North, R.P., North, R.L., Livingstone, D.M., Köster, O., Kipfer, R., 2014. Long-term changes in hypoxia and soluble reactive phosphorus in the hypolimnion of a large temperate lake: consequences of a climate regime shift. Global Change Biol. 20, 811-823. https://doi.org/10.1111/gcb.12371

Nutrient Management Act, S.O. 2002, c.4. Retrieved June 1 ${ }^{\text {st }}, 2017$ from https://www.ontario.ca/laws/statute/02n04.

Oksanen, J., Blanchet, F.G., Kindt, R., Legendre, P., Minchin, P.R., O’Hara, R.B., Simpson, G.L., Solymos, P., Stevens, M.H.H., Wagner, H., 2015. vegan: Community Ecology Package. R package version 2.2-1. http://cran.R-project.org/package=vegan. 
656 Paerl, H.W., Hall, N.S., Calandrino, E.S., 2011. Controlling harmful cyanobacterial blooms in a world experiencing anthropogenic and climatic-induced change. Sci. Total Environ. 409, 1739-1745. https://doi.org/10.1016/j.scitotenv.2011.02.001

659 Paerl, H.W., Huisman, J., 2008. Blooms like It Hot. Science 320, 57-58.

660 Pilon, R.E., Chrétien, R.-M., 1991. St. Lawrence beaches study: 1990 summary report. Report prepared for the Raisin Region Conservation Authority. Retrieved March 15 ${ }^{\text {th }}, 2016$ from

R Core Team, 2015. R: A language and environment for statistical computing.

664 Rao, C.R., 1995. A review of canonical coordinates and an alternative to correspondence analysis using Hellinger distance. Qüestiió 19, 23-63.

666 Reavie, E.D., Edlund, M.B., 2010. Diatoms as indicators of long-term environmental change in rivers, fluvial lakes, and impoundments, in: Smol, J.P., Stoermer, E.F. (Eds.), The Diatoms: Applications for the Environmental and Earth Sciences. Cambridge University Press, Cambridge, UK, p. 667.

Reavie, E. D., Smol, J. P., 1997. Diatom-based model to infer past littoral habitat characteristics in the St. Lawrence River. J. Great Lakes Res. 23, 339-348.

672 Reavie, E.D., Smol, J.P., 1998. Freshwater diatoms from the St. Lawrence River, in: LangeBertalot, H., Kociolek, P. (Eds.), Biblioteca Diatomologica: Band 41. Gebruder Borntraeger, Stuttgart.

Reavie, E.D., Smol, J.P., Carignan, R., Lorrain, S., 1998. Diatom paleolimnology of two fluvial lakes in the St. Lawrence River: a reconstruction of environmental changes during the last century. J. Phycol. 34, 446-456. 
678 Richman, L.A., Rupert, G., Young, H., 1997. St. Lawrence River Remedial Action Plan: $679 \quad$ Technical Report \#8.

680 Savage, C., Leavitt, P.R., Elmgren, R., 2010. Effects of land use, urbanization, and climate variability on coastal eutrophication in the Baltic Sea. Limnol. Oceanogr. 55, 1033-1046.

683 Savard, L., Marty, J., Waller, M.E., Bramburger, A.J., 2013. Mapping water quality in Lake St Francis nearshore areas of the St. Lawrence River. Prepared by the SLRIES for the

Savard, L., Razavi, R., Ridal, J., 2015. Characterization of tributary phosphorus inputs to Lake Ontario Ministry of the Environment and Climate Change. https://doi.org/10.4319/1o.2010.55.3.1033

St. Francis nearshore areas of the St. Lawrence River. Prepared for the SLRIES for the Ontario Ministry of the Environment and Climate Change. St. Lawrence River Institute of Environmental Sciences, Cornwall, Ontario.

Schelske, C., Peplow, A., Brenner, M., Spencer, C., 1994. Low-background gamma counting: applications for 210Pb dating of sediments. J. Paleolimnol. 10, 115-128. https://doi.org/10.1007/BF00682508

Schelske, C.L., 1991. Historical nutrient enrichment of Lake Ontario: paleolimnological evidence. Can. J. Fish. Aquat. Sci. 48, 1529-1538. https://doi.org/10.1139/f91-181

Smith, P.G.R., 2015. Long-term temporal trends in agri-environment and agricultural land use in Ontario, Canada: transformation, transition and significance. J. Geogr. Geol. 7, 32-55. https://doi.org/10.5539/jgg.v7n2p32

Stein, J., 1995. Time, space and social discipline: factory life in Cornwall, Ontario, 1867-1893. 
700 The St. Lawrence River (Cornwall) RAP Team, 1995. Addendum to stage 1 report: St. Lawrence $701 \quad$ River remedial action plan, Cornwall/Lake St. Francis area.

702 Waller, M.E., Bramburger, A.J., Cumming, B.F., 2016. Bi-weekly changes in phytoplankton 703 abundance in 25 tributaries of Lake St. Francis, Canada: evaluating the occurrence of nuisance and harmful algae. J. Great Lakes Res. 42, 1049-1059. https://doi.org/10.1016/j.jglr.2016.07.003

706 Yee, P., Edgett, R., Eberhardt, A., 1990. Great Lakes - St. Lawrence River regulation: What it 707 means and how it works. Retrieved November $29^{\text {th }}, 2016$ from

708 http://ijc.org/files/tinymce/uploaded/ISLRBC/Great\%20Lakes-

709 St.\%20Lawrence\%20River\%20Regulation_1993_e.pdf.

710 
713 Figure 1. A) The Laurentian Great Lakes and St. Lawrence River with inset indicating towns of

714 interest and the Area of Concern (the hatched area). B) Sampling location (indicated by the "X"),

715 Lake St. Francis bathymetry, and nearby tributaries. C) Bathymetry of Lake St. Francis within

716 the Area of Concern, land use of the nine major watersheds in Ontario that contribute to the St.

717 Lawrence River Area of Concern, and locations of nearby dams and Cornwall wastewater

718 treatment plant (WWTP); the extent of panel B is indicated by the rectangle.

720 Figure 2. A) Activities and errors of the four radioisotopes, by depth in the sediment core,

721 measured through gamma spectroscopy. B) Inferred year, sedimentation rate, and associated

722 errors as calculated through the constant rate of supply (CRS) model.

724 Figure 3. Concentrations of photosynthetic pigments (per gram organic matter) throughout the

725 sediment core. Secondary y-axis indicates year inferred from the constant rate of supply (CRS)

726 dating model. Top panel: more stable pigments, defined as a category 1 (Leavitt and Hodgson,

727 2001). Bottom panel: more labile pigments, defined as a category 2, 3, or 4 (Leavitt and

728 Hodgson, 2001) and ratio of chlorophyll $a$ to phaeophytin $a$, an indicator of the extent of pigment

729 degradation.

731 Figure 4. Percent organic matter, per mille ratios of stable isotopes, and mass ratio of carbon to

732 nitrogen by depth and year inferred through the constant rate of supply (CRS) dating model. 
734 Figure 5. A) Diatom valve concentrations by depth and year inferred through the constant rate of

735 supply (CRS) dating model. B, C) Relative abundances of the dominant (B) and subdominant (C)

736 diatom species observed in the core. The dotted line represents the significant assemblage change

737 identified by the broken stick model and constrained incremental sum of squares. 

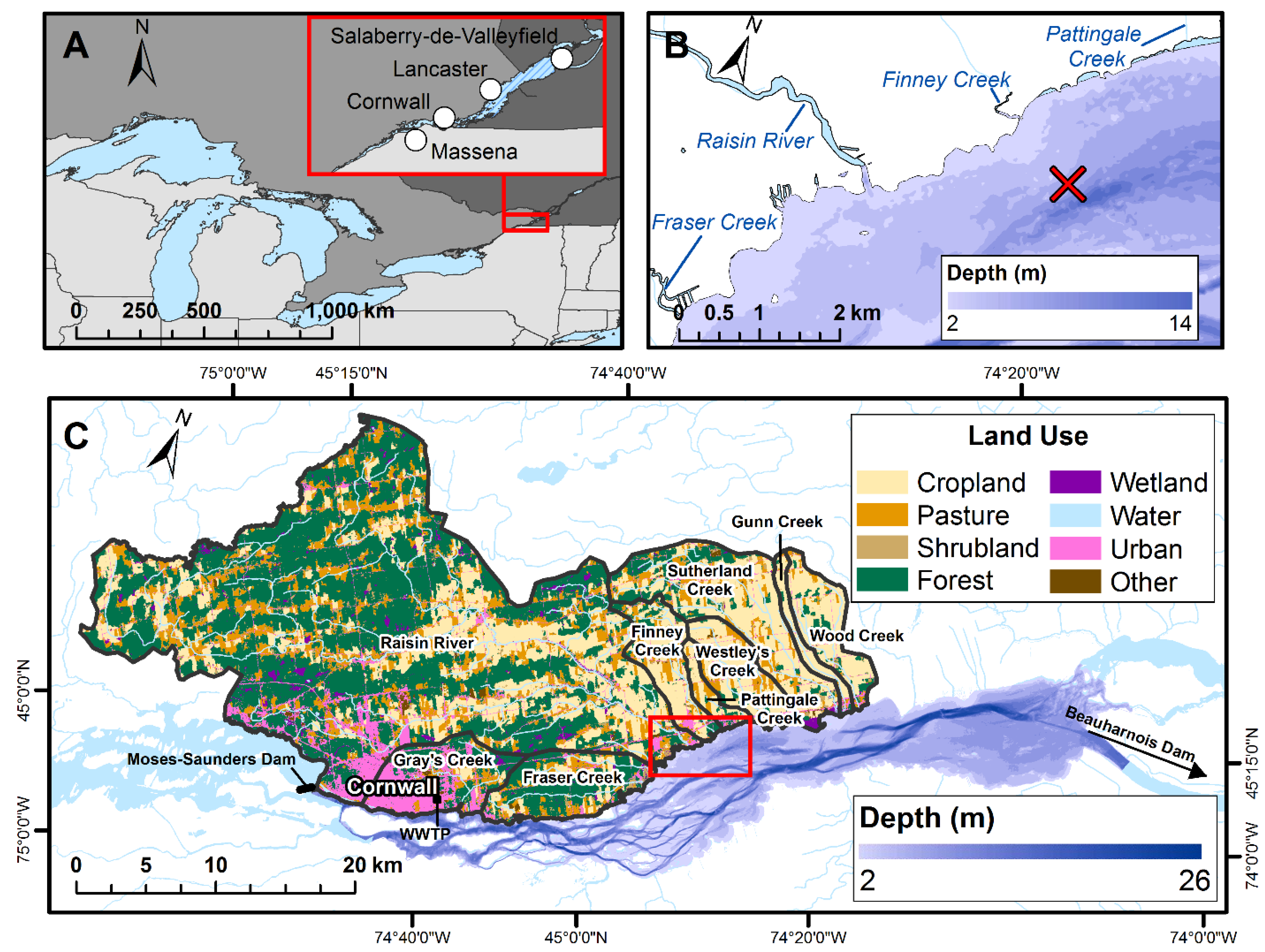

Figure 1. A) The Laurentian Great Lakes and St. Lawrence River with inset indicating towns of interest and the Area of Concern (the hatched area). B) Sampling location (indicated by the " $X$ "), St. Lawrence River bathymetry, and nearby tributaries. C) Bathymetry of the St. Lawrence River within the Area of Concern, land use of the nine major contributing watersheds in Ontario to the St. Lawrence River, and locations of nearby dams and Cornwall wastewater treatment plant (WWTP); the extent of panel B is indicated by the rectangle. 

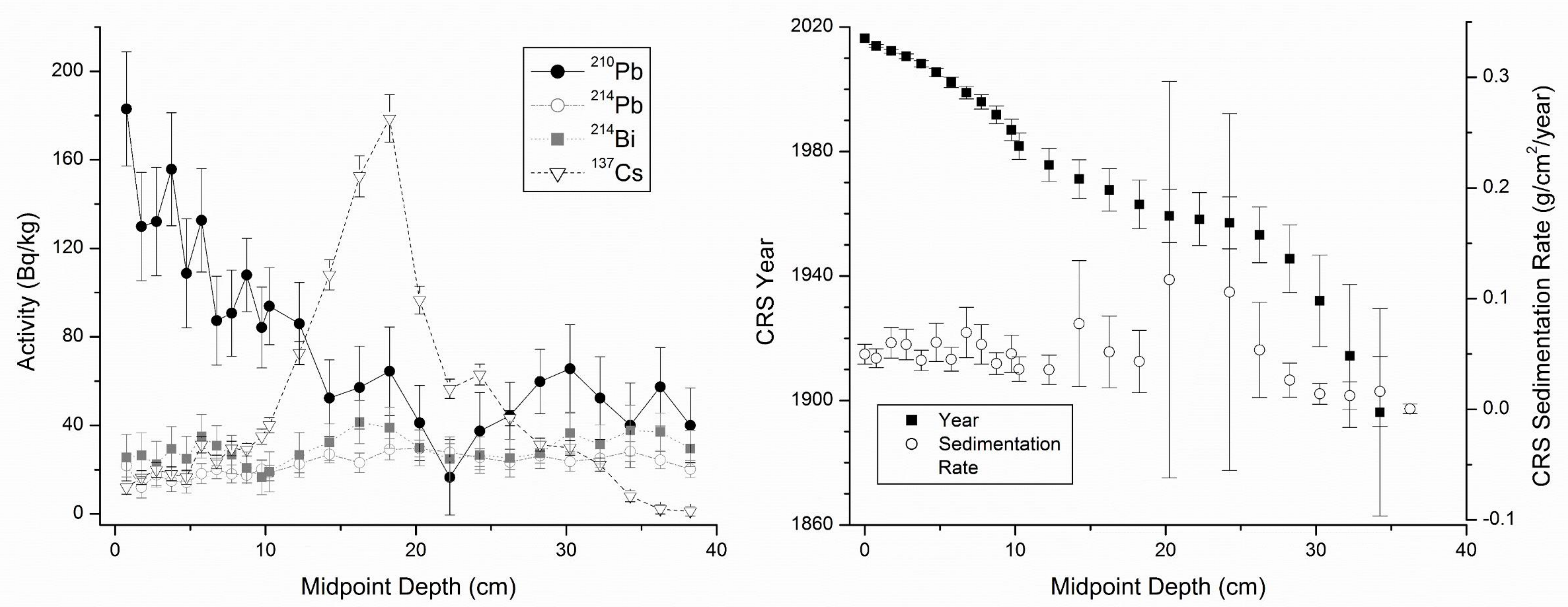

Figure 2. A) Activities and errors of the four radioisotopes, by depth in the sediment core, measured through gamma spectroscopy. B) Inferred year, sedimentation rate, and associated errors as calculated through the constant rate of supply (CRS) model. 

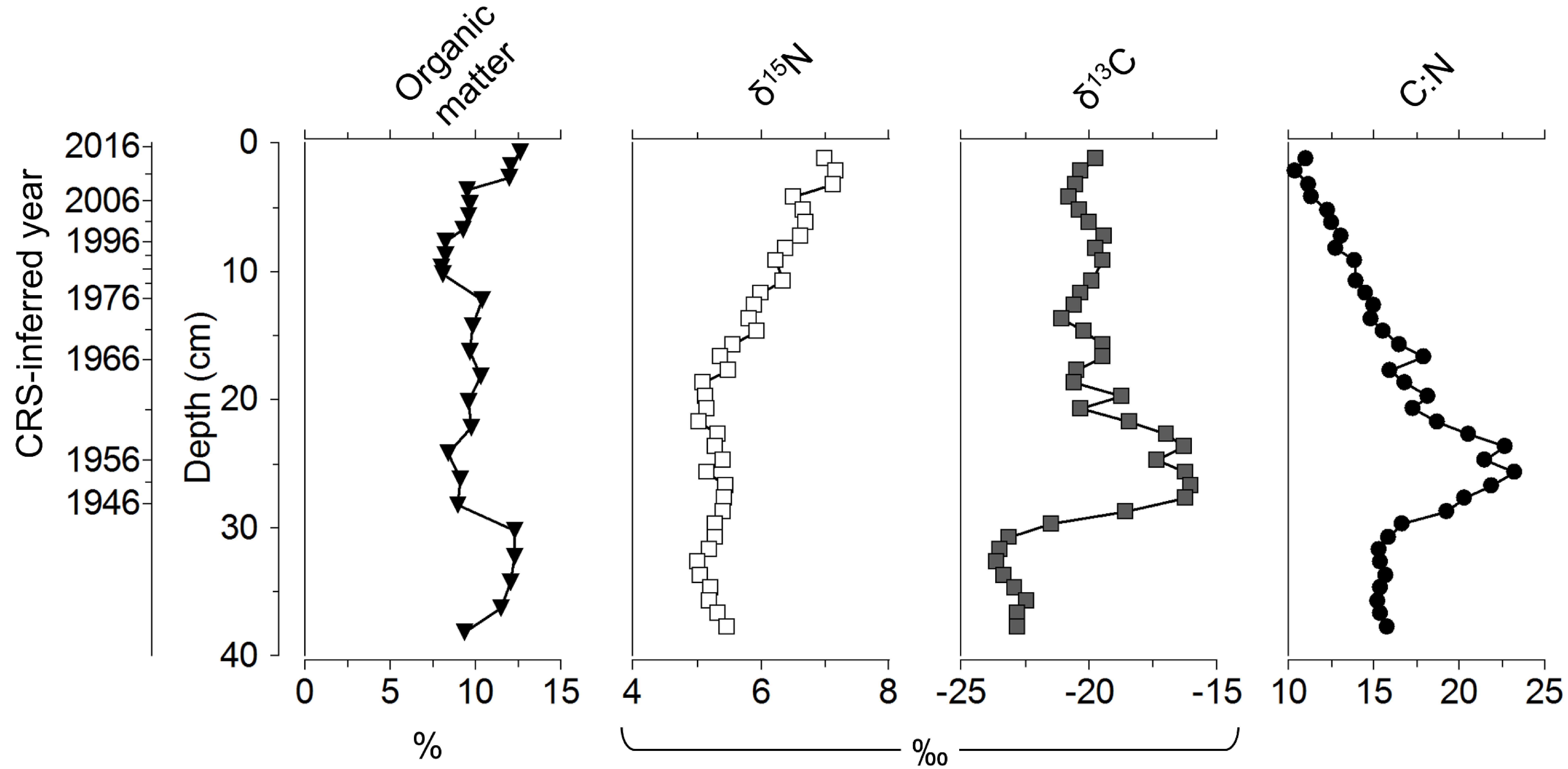

Figure 4. Percent organic matter and ratios of stable isotopes by depth and year inferred through the constant rate of supply (CRS) dating model. The box indicates inferred years during which the MosesSaunders Power Dam was constructed (1954-1959). 


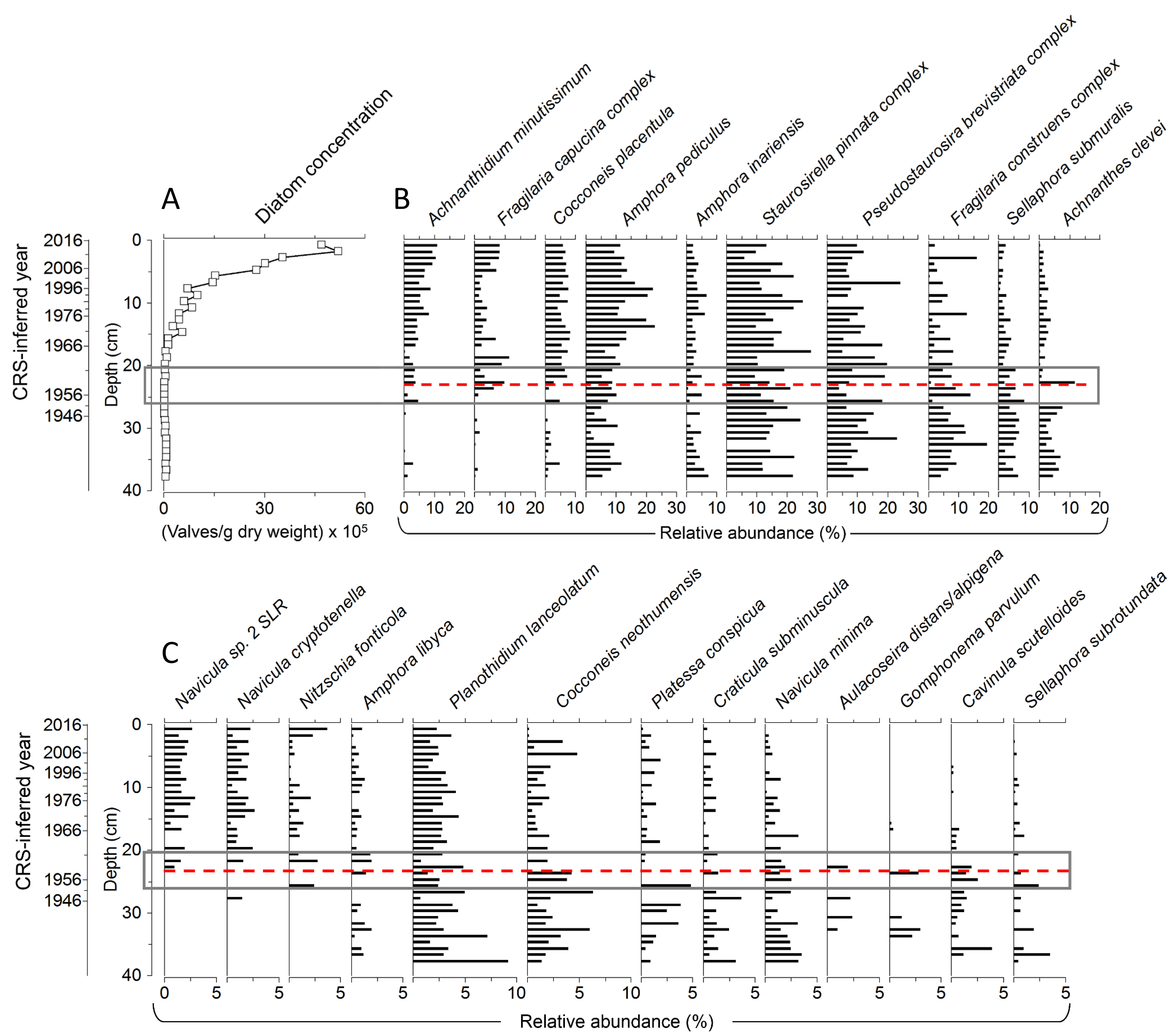

Figure 5. A) Diatom concentrations by depth and year inferred through the constant rate of supply (CRS) dating model. B, C) Relative abundances of the dominant (B) and subdominant (C) diatom species observed in the core. The dotted line represents the significant assemblage change identified by the broken stick model and constrained incremental sum of squares. The box indicates inferred years during which the Moses-Saunders Power Dam was constructed (1954-1959). 